\title{
Organ and tissue donation in clinical settings: a systematic review of the impact of interventions aimed at health professionals
}

\author{
Frédéric Douville ${ }^{1 *}$, Gaston Godin ${ }^{2}$ and Lydi-Anne Vézina-Im²
}

\begin{abstract}
In countries where presumed consent for organ donation does not apply, health professionals (HP) are key players for identifying donors and obtaining their consent. This systematic review was designed to verify the efficacy of interventions aimed at HPs to promote organ and tissue donation in clinical settings. CINAHL (1982 to 2012), COCHRANE LIBRARY, EMBASE (1974 to 2012), MEDLINE (1966 to 2012), PsycINFO (1960 to 2012), and ProQuest Dissertations and Theses were searched for papers published in French or English until September 2012. Studies were considered if they met the following criteria: aimed at improving HPs' practices regarding the donation process or at increasing donation rates; HPs working in clinical settings; and interventions with a control group or pre-post assessments. Intervention behavioral change techniques were analyzed using a validated taxonomy. A risk ratio was computed for each study having a control group. A total of 15 studies were identified, of which only 5 had a control group. Interventions were either educational, organizational or a combination of both, and had a weak theoretical basis. The most common behavior change technique was providing instruction. Two sets of interventions showed a significant risk ratio. However, most studies did not report the information needed to compute their efficacy. Therefore, interventions aimed at improving the donation process or at increasing donation rates should be based on sound theoretical frameworks. They would benefit from more rigorous evaluation methods to ensure good knowledge translation and appropriate organizational decisions to improve professional practices.
\end{abstract}

Keywords: tissue and organ procurement, health professional, program development, professional education, hospital

\section{Review}

\section{Background}

The number of patients awaiting organ or tissue transplantation continues to grow throughout the world [1-4]. The shortage of organ and tissue donors is widely studied and several factors explaining why individuals accept or refuse to consent to organ and tissue donation are reported in the literature [5]. Simpkin et al. [6] conducted a review of modifiable factors that influence relatives' decisions to allow organ donation. This review suggests that the skills of individuals making the request to donate may have a significant impact on consent rates. Based on this information, evaluating the efficacy of interventions among HPs to increase donation seems relevant.

\footnotetext{
${ }^{*}$ Correspondence: frederic.douville@fsi.ulaval.ca

'Institut universitaire de cardiologie et de pneumologie de Québec, 2725, chemin Sainte-Foy, Room Y-3495, Quebec, (Quebec) G1V 4G5, Canada Full list of author information is available at the end of the article
}

The donation process depends on potential donor identification and on HPs approaching families for donation consent. Since HPs are responsible for this approach to families, they are the gatekeepers for organ and tissue donor notification.

Consent to organ and tissue donation is the end point resulting from many actions undertaken by HPs (from identifying potential donors to referring donors to an organ and tissue procurement representative). In fact, many of these actions can be viewed as professional practices and as forms of human behavior. Thus, interventions should take advantage of behavioral theories and behavior change strategies in their design [7-11]. Past studies have demonstrated the importance of developing theory-based interventions in order to enhance their potential success in changing behavior $[12,13]$. The absence of theoretical bases for interventions and the selection of appropriate behavioral change techniques are two of the main problems in

\section{Biomed Central}


behavior change research projects [14-17]. Grimshaw et al. [15] suggest exploring the applicability of behavioral theories to the understanding of behavior change among HPs.

Several systematic reviews on organ donation have been published. These systematic reviews have cover different aspects of organ donation including the factors influencing families consent to donation [6], the attitude of the public towards living donors [18], the educational interventions offered in high schools [19], the management of donor brain death [20] and professional's attitude regarding the heart-beating donors [21]. However, there is no systematic review on the efficacy of interventions among HPs to encourage them to approach families for consent or increasing donation rates. This is an important aspect of organ donation because donor identification and obtaining the consent of family are necessary conditions to the donation process.

This systematic review was designed to identify and analyze the impact of interventions aimed at HPs to improve donation-promoting professional practices in clinical settings. Secondary outcomes consisted of verifying whether such interventions were effective in improving donation rates and exploring associated behavior change strategies and the underlying theoretical framework.

\section{Methods}

\section{Search strategy}

The most relevant electronic databases covering the field of behavior change among HPs are those in health and psychology. CINAHL (1982-2012), COCHRANE LIBRA RY (Cochrane Reviews, Other Reviews, Trials, Methods Studies, Technology Assessments, Economic Evaluations, Cochrane Groups), EMBASE (1974-2012), MEDLINE (1966-2012), PsycINFO (1960-2012), and ProQuest Dissertations and Theses were searched for papers published in French or English until September 2012.

The search strategy included the following concepts: 1) health professionals; 2) organ and tissue donation; and 3) interventions or strategies. This search strategy was adapted according to the terminology of the various databases. Moreover, bibliographies of potential studies were analyzed manually to find other key words relevant to the search strategy and studies not identified with the main search strategy. Only French and English papers were considered for review for practical reasons. The complete search strategy for each database is presented in Additional file 1.

\section{Study eligibility criteria}

To be eligible for inclusion, studies had to adopt an experimental or quasi-experimental design reporting interventions aimed at HPs in clinical settings in order to improve their practices regarding the donation process or to increase the donation rates. They also had to report behavioral measures of the donation process or impact on organ and tissue donation rates as the study outcome.

In this study, HPs refer to professionals with medical training whose jobs require them to be in contact with patients and who are in a position to ask for donor consent. The concept of HP includes family physicians, specialist physicians, nurses or any other allied HPs who meet families in their daily practice. It also includes physicians in training (residents or interns), but excludes healthcare students and administrators not in contact with patients.

Also, the interventions had to be offered to HPs with the intention of modifying their practice regarding the donation process or at increasing donation rates. Such interventions could take the form of educational (for example, flyers, workshop, or lecture) [22,23], organizational (for example, hospital personnel structure change, or guidelines) [24], or regulatory strategies. These interventions or strategies were retained insofar as they were aimed at HPs caring for patients.

From a methodological point of view, the studies had to include a control group. However, to ensure that the study would not overlook relevant interventions that might have been effective, intervention studies without a control group, but with a pre-post analysis, were considered in a separate analysis.

Finally, to be included in the review, the intervention outcome had to be reported as a behavioral measure of the donation process (objective or self-reported), based on Kirkpatrick's third level of program evaluation [25], or as the impact on organ and tissue donation rates. Behavioral measures could be a specific action (behavior) in the donation process, such as identifying a potential donor, approaching families to initiate discussion, obtaining signed consent for a donation or referring a potential donor to an organ and tissue donor representative. Articles reporting the impact on organ and tissue donation rates were considered even if the study did not assess behavioral outcomes to ensure comprehensiveness of the interventions reported in this review.

Studies that did not include HPs were excluded, as were those not directly aimed at changing HPs' behavior, such as the implementation of an Organ Procurement Organization (OPO) coordinator in a hospital. Although one of the OPO's duties involves identifying potential donors and approaching families to initiate donation discussion, their implementation could not be considered as an intervention intended for HPs (nurses and physicians) to modify their practices regarding the donation process; the latter would still have to notify the OPO and procurement organizations of potential organ and tissue donors.

Finally, studies concerning HPs' reactions following an intervention or their level of knowledge following the intervention [25] were not considered if the assessed outcomes did not include the HPs' behavior or donation rate. 
Sorting of the studies by their titles and abstracts was first carried out by FD in order to select the articles meeting the inclusion criteria. Thereafter, the full text articles that met the inclusion criteria were screened independently by FD and LAVI, and decisions were compared.

\section{Study quality assessment}

Quality assessment of the studies was performed using criteria inspired by Morrison [26] and Reed [27], who recommend questions for appraising reports of medical education interventions.

Three criteria were selected to assess the population (randomized sample; justification of sample size and existence of a control group). Two criteria evaluated the intervention (allocation concealment and theory underlying the intervention). Two criteria appraised the assessment tool (validity and reliability). Finally, two criteria assessed the statistical approach used (intention-to-treat) and the level of attrition at follow-up.

No assessment for the risk of bias across studies was performed because the interventions had different objectives, populations and outcomes, making it impossible to obtain cumulative evidence.

\section{Data extraction}

A first coding was carried out on one study to verify if there was agreement on the extraction of data and to confirm the quality of the coding sheet. In case of disagreement between the two reviewers, the final decision was taken after discussion with a third reviewer (GG).

The following data were extracted from the selected studies: authors, year of publication, population under study and sample size. The study data were extracted according to the recommendations for evaluating educational interventions $[26,27]$. Thus, the reported variables were: objective of the study; intervention type (educational or organizational) and strategy; duration of follow-up; behavior change techniques; and study methodology, outcomes and results. The theory underlying each intervention was also extracted.

To help classify HPs' strategies and relate those to the most recognized and effective theory-based strategies, behavior change techniques were analyzed using the taxonomy developed by Abraham and Michie as reference [11]. This taxonomy contains 26 behavior change techniques used in interventions based on behavior change theories such as the theory of reasoned action [28], the theory of planned behavior [29], the social cognitive theory [30], the information-motivation-behavioral skills models [31] and other behavior change theories.

\section{Data analyses}

Based on the studies retained, a descriptive analysis of selected studies (study objective; intervention type (educational or organizational) and strategy adopted; duration of the follow-up; behavior change techniques used; and study methodology, outcomes and results) was completed prior to identifying effective interventions. Interventions with a control group and interventions with a pre-post analysis are described separately.

A risk ratio was calculated for each outcome among the studies with a control group. The risk ratio was determined based on the number of participants in each group (experimental and control) and on the frequency of HPs' behavior adoption. Thus, the analysis allowed the identification of significant differences between the two groups following the implementation of an intervention.

\section{Results}

\section{Review statistics}

A total of 15 studies assessing interventions among HPs in clinical settings aimed at improving professional practices regarding the donation process or increasing donation rates were identified. The results of the search strategy are presented in Figure 1. All studies included used educational, organizational or a combination of both types of interventions to promote professional practices regarding the donation process. These took the form of in-service meetings, workshops, conferences, print documents, examples provided of situations associated with the organ and tissue donation process and identification of donation criteria or information on how to approach a potential donor $[23,32,33]$.

\section{Study quality assessment}

The 15 studies were assessed regarding population and the intervention assessment tool. In general, study quality was low. No study used a randomized population or justified their sample size. Only five studies used a control group. Allocation concealment of the intervention was neither relevant nor mentioned for all the studies included, and 14 of the 15 studies did not use a theory-based intervention. Where relevant, the validity and reliability of the assessment tools were not mentioned. Among the studies with a control group, there was no intention-totreat analysis. Finally, the attrition rate was appropriately mentioned when required. The results of the quality assessment for the studies of the present review are available in Table 1.

\section{Efficacy of the interventions}

\section{Intervention studies with comparison groups}

Among the 15 studies included, only five had a comparison group (Table 2) [23,32-35]. The specific populations in these studies were nurses [32-34], physicians [23,33,34] and residents in medicine [35]. In addition to HPs, three studies also included other allied HPs such as chaplains or administrators [32-34]. All the studies used educational 


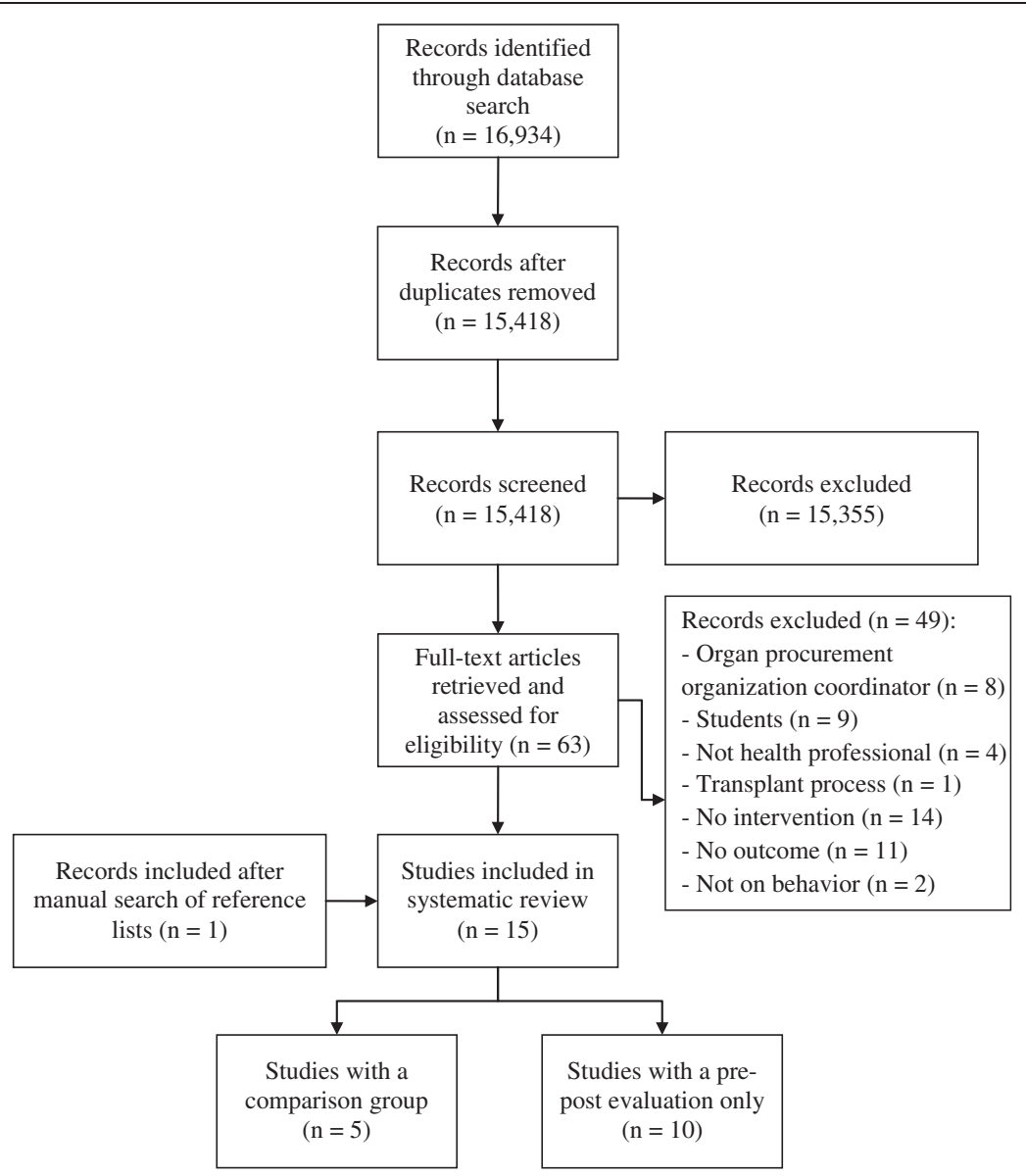

Figure 1 Flow chart diagram.

interventions to increase donation and one also used an organizational strategy. None of these interventions were based on a theoretical framework. According to the list of behavior change techniques [11], the majority of the strategies provided instruction on the donation process, the HPs' role or how to cope with families' reactions.

Relative risks (risk ratios) were computed to determine how likely participants were to adopt a behavior related to organ and tissue donation following an intervention, compared with those not exposed to the intervention (Table 3). Due to a high level of heterogeneity, the relative risks were calculated independently for each study and not pooled together.

The intervention studies of Nelson et al. [33] and Riker and White [23] showed significant relative risks for the following: approaching families [23,33], referring potential donors [33] and increasing donation rates [23]. However, the interventions of Dettle et al. [32], Light [35] and Riker and White [23] did not result in a significant increase in the number of signed consents for donation. No relative risk could be computed for the interventions of Kittur et al. [34], since the results were presented in absolute numbers instead of percentages, and there were no data on the total size of the groups.

\section{Intervention studies without a comparison group (pre-post assessments)}

The remaining ten studies used pre-post assessments (Table 4) [36-45]. These studies evaluated behavior change toward donation among HPs or the impact of their intervention on donation rates. The participants targeted in these interventions were mainly nurses and physicians. However, six of these studies involved hospital staff, without specifying which types of HPs were targeted $[36,38,40,42,44,45]$. Also, in six of the ten studies, the number of participants was not provided [36,37,41-44].

All the studies used educational strategies or a combination of organizational and educational strategies to promote donation behavior among HPs. In the study of Taylor et al. [41], there were references to the concept of change theory in the development of their intervention, but none of the other studies used a theoretical framework to guide the development of their intervention. The most common technique was to provide instruction on the 
Table 1 Summary of quality assessment for the studies included

\begin{tabular}{|c|c|c|c|c|c|c|c|c|c|}
\hline \multirow[b]{2}{*}{ Papers } & \multicolumn{3}{|c|}{ Population } & \multicolumn{2}{|c|}{ Intervention } & \multicolumn{2}{|c|}{ Assessment tool(s) ${ }^{a}$} & \multicolumn{2}{|c|}{ Analysis } \\
\hline & Randomization & $\begin{array}{l}\text { Justification of } \\
\text { sample size }\end{array}$ & Control group & $\begin{array}{l}\text { Allocation } \\
\text { concealment }\end{array}$ & $\begin{array}{l}\text { Underlying } \\
\text { theory }\end{array}$ & Validity & Reliability & $\begin{array}{l}\text { Intention- } \\
\text { to-treat }\end{array}$ & $\begin{array}{l}\text { Attrition } \\
\text { rate }\end{array}$ \\
\hline Alonso, Fernandez, Mataix et al. (1999) & No & Not mentioned & No & $\mathrm{N} / \mathrm{A}$ & None & $\mathrm{N} / \mathrm{A}$ & N/A & $\mathrm{N} / \mathrm{A}$ & N/A \\
\hline $\begin{array}{l}\text { Beasley, Capossela, Brigham, } \\
\text { Gunderson and Gortmaker (1997) }\end{array}$ & No & No & No & N/A & None & N/A & N/A & N/A & N/A \\
\hline Bleakley (2010) & No & No & No & N/A & None & N/A & N/A & N/A & N/A \\
\hline Dettle, Sagel and Chrysler (1994) & No & No & $\begin{array}{l}\text { Yes (but no statistical } \\
\text { comparison between } \\
\text { groups) }\end{array}$ & Not mentioned & None & $\begin{array}{l}\text { Not } \\
\text { mentioned }\end{array}$ & $\begin{array}{l}\text { Not } \\
\text { mentioned }\end{array}$ & no & $\begin{array}{l}40 \% \text { attrition; } \\
\text { No analysis } \\
\text { of dropouts }\end{array}$ \\
\hline Kittur, McMenamin and Knott (1990) & No & No & Yes & Not randomly assigned & None & N/A & N/A & N/A & N/A \\
\hline Light (1987) & No & No & $\begin{array}{l}\text { Yes (but no statistical } \\
\text { comparison between } \\
\text { groups) }\end{array}$ & Not randomly assigned & None & N/A & N/A & N/A & N/A \\
\hline $\begin{array}{l}\text { Milanés, Gonzalez, Hernandez, Arminio, } \\
\text { Clesca and Rivas-Vetencourt (2003) }\end{array}$ & No & No & No & N/A & None & N/A & N/A & N/A & N/A \\
\hline $\begin{array}{l}\text { Nelson, Marymont, Durand, } \\
\text { Reyes and Davis (1992) }\end{array}$ & $\begin{array}{l}\text { Random cluster } \\
\text { probability method }\end{array}$ & No & Yes & Not randomly assigned & None & $\begin{array}{l}\text { Field testing } \\
\text { questionnai } \\
\text { reliability as } \\
\text { detailed) }\end{array}$ & $\begin{array}{l}\text { of the } \\
\text { (but validity/ } \\
\text { assment not }\end{array}$ & N/A & N/A \\
\hline Niday, Painter, Peak et al. (2007) & No & No & No & N/A & None & N/A & N/A & N/A & N/A \\
\hline Riker and White (1995) & No & No & Yes & $\begin{array}{l}\text { Not randomly } \\
\text { assigned }\end{array}$ & None & N/A & N/A & N/A & N/A \\
\hline Shafer, Durand, Hueneke, et al. (1998) & No & No & No & N/A & None & N/A & N/A & N/A & N/A \\
\hline Stark, Wikoren and Martone (1994) & No & No & No & $\mathrm{N} / \mathrm{A}$ & None & N/A & N/A & N/A & N/A \\
\hline Taylor, Young and Kneteman (1997) & No & No & No & N/A & $\begin{array}{l}\text { 'Change theory' } \\
\text { (not referenced) }\end{array}$ & N/A & N/A & N/A & N/A \\
\hline $\begin{array}{l}\text { Van Gelder, Van Hees, de Roey, } \\
\text { Monbaliu, Aerts, Coosemans et al. (2006) }\end{array}$ & No & No & No & N/A & None & N/A & N/A & N/A & N/A \\
\hline Wight, Cohen, Roels and Miranda (2000) & No & No & No & N/A & None & N/A & N/A & N/A & N/A \\
\hline
\end{tabular}

The assessment tools assessed were only those regarding outcomes assessed in this systematic review, that is, professional practices or donation rates; when the outcome was an objective measure (donation rate or any quantitative item retrieved from medical records review), validity and reliability were considered nonapplicable.

N/A, not applicable. 
Table 2 Description of the interventions on organ and tissue donation with comparison groups

\begin{tabular}{|c|c|c|c|c|c|c|c|c|}
\hline $\begin{array}{l}\text { Authors (year); } \\
\text { country }\end{array}$ & Purposes & Populations (n) & Interventions & Follow-up & $\begin{array}{l}\text { Behavior } \\
\text { change technique }\end{array}$ & $\begin{array}{l}\text { Study } \\
\text { methodology }\end{array}$ & Outcomes & $\begin{array}{l}\text { Results } \\
\text { (Experimental } \\
\text { versus Control) }\end{array}$ \\
\hline \multirow{4}{*}{$\begin{array}{l}\text { Dettle, Sagel and } \\
\text { Chrysler (1994); } \\
\text { United States }\end{array}$} & \multirow{4}{*}{$\begin{array}{l}\text { To gain a better understanding of } \\
\text { health care professionals' experience, } \\
\text { knowledge, attitudes, and comfort } \\
\text { level regarding organ and tissue } \\
\text { donation }\end{array}$} & \multirow{4}{*}{$\begin{array}{l}\text { Nurses and Chaplains } \\
(n=343)\end{array}$} & Educational: & \multirow[t]{4}{*}{6 months } & \multirow[t]{4}{*}{ - Provide instruction } & \multirow{4}{*}{$\begin{array}{l}\text { Health } \\
\text { professionals } \\
\text { survey }\end{array}$} & \multirow{4}{*}{$\begin{array}{l}\text { Approached } \\
\text { family }\end{array}$} & \multirow{2}{*}{$\begin{array}{l}\text { Experimental } \\
18 \% \rightarrow 38 \% \\
(P=.039)\end{array}$} \\
\hline & & & $\begin{array}{l}\text { - Formal in-service on organ } \\
\text { and tissue donation }\end{array}$ & & & & & \\
\hline & & & $\begin{array}{l}\text { - Unit meeting addressing } \\
\text { donation issues }\end{array}$ & & & & & \multirow[t]{2}{*}{$\begin{array}{l}\text { Control } 4 \% \rightarrow \\
25 \%(P<.001)\end{array}$} \\
\hline & & & $\begin{array}{l}\text { - Dealing with a family of } \\
\text { an actual donor }\end{array}$ & & & & & \\
\hline \multirow{6}{*}{$\begin{array}{l}\text { Kittur, McMenamin } \\
\text { and Knott (1990); } \\
\text { United States }\end{array}$} & \multirow{6}{*}{$\begin{array}{l}\text { To evaluate the impact of an organ } \\
\text { donor and tissue donor advocacy } \\
\text { program on community hospitals }\end{array}$} & \multirow{6}{*}{$\begin{array}{l}\text { Hospital staff: } \\
\text { physicians, nurses } \\
\text { and administrators } \\
(n=\text { not mentioned })\end{array}$} & Educational: & \multirow[t]{6}{*}{12 months } & - Provide instruction & \multirow{6}{*}{$\begin{array}{l}\text { Not } \\
\text { mentioned }\end{array}$} & \multirow{2}{*}{$\begin{array}{l}\text { Referred } \\
\text { potential donor }\end{array}$} & \multirow{2}{*}{$\begin{array}{l}44 \text { donors versus } \\
2 \text { donors }\end{array}$} \\
\hline & & & $\begin{array}{l}\text { - Hospital's organ and tissue } \\
\text { donation policies and procedures }\end{array}$ & & $\begin{array}{l}\text { - Provide } \\
\text { contingent rewards }\end{array}$ & & & \\
\hline & & & $\begin{array}{l}\text { - Sending letter of gratitude } \\
\text { to requestors }\end{array}$ & & \multirow[t]{4}{*}{$\begin{array}{l}\text { - Teach to use } \\
\text { prompts or cues }\end{array}$} & & \multirow{4}{*}{$\begin{array}{l}\text { Organ and/or } \\
\text { tissue donor } \\
\text { recovered }\end{array}$} & \multirow[t]{4}{*}{$\begin{array}{l}18 \text { donors versus } \\
1 \text { donor }\end{array}$} \\
\hline & & & $\begin{array}{l}\text { - Sending letter reminding to } \\
\text { request all eligible patients }\end{array}$ & & & & & \\
\hline & & & Organizational: & & & & & \\
\hline & & & $\begin{array}{l}\text { - Developing a donor } \\
\text { advocate role }\end{array}$ & & & & & \\
\hline \multirow[t]{2}{*}{$\begin{array}{l}\text { Light (1987); } \\
\text { United States }\end{array}$} & \multirow{2}{*}{$\begin{array}{l}\text { To evaluate the efficacy of including } \\
\text { printed criteria and procedures with } \\
\text { the autopsy permits as a simple, } \\
\text { inexpensive method of increasing } \\
\text { cornea donation }\end{array}$} & \multirow[t]{2}{*}{ Residents $(n=84)$} & Educational: & \multirow[t]{2}{*}{4 months } & $\begin{array}{l}\text { - Provide } \\
\text { information on } \\
\text { consequence }\end{array}$ & \multirow[t]{2}{*}{$\begin{array}{l}\text { Eye bank data } \\
\text { analysis }\end{array}$} & \multirow[t]{2}{*}{$\begin{array}{l}\text { Organ and/or } \\
\text { tissue donor } \\
\text { recovered }\end{array}$} & $\begin{array}{l}\text { Experimental } \\
1.8 \% \rightarrow 10.2 \% \\
(P=.009)\end{array}$ \\
\hline & & & $\begin{array}{l}\text { - Instruction for cornea donation } \\
\text { and a checklist of donation } \\
\text { procedures }\end{array}$ & & - Provide instruction & & & $\begin{array}{l}\text { Control } \\
7.1 \% \rightarrow 8.5 \% \\
\text { (not significant) }\end{array}$ \\
\hline \multirow{7}{*}{$\begin{array}{l}\text { Nelson, Marymont, } \\
\text { Durand, Reyes and } \\
\text { Davis (1992); } \\
\text { United States }\end{array}$} & \multirow{7}{*}{$\begin{array}{l}\text { To examine the organ procurement } \\
\text { organization's educational activities } \\
\text { and their effects on attitudes, } \\
\text { knowledge, and referral behavior }\end{array}$} & \multirow{7}{*}{$\begin{array}{l}\text { Nurses, physicians } \\
\text { and chaplains } \\
(n=265)\end{array}$} & Educational: & \multirow{7}{*}{$\begin{array}{l}\text { Not } \\
\text { mentioned }\end{array}$} & \multirow{7}{*}{$\begin{array}{l}\text { - Intervention not } \\
\text { described }\end{array}$} & \multirow{7}{*}{$\begin{array}{l}\text { Health } \\
\text { professionals } \\
\text { survey }\end{array}$} & \multirow{6}{*}{$\begin{array}{l}\text { Approached } \\
\text { family }\end{array}$} & \multirow{6}{*}{$\begin{array}{l}59 \% \text { versus } 46 \% \\
(P=.027)\end{array}$} \\
\hline & & & - Continuing medical education & & & & & \\
\hline & & & - Newsletters & & & & & \\
\hline & & & - Other publications & & & & & \\
\hline & & & - Requestor's workshop & & & & & \\
\hline & & & - In-service training session & & & & & \\
\hline & & & - Others programs & & & & $\begin{array}{l}\text { Referred } \\
\text { potential donor }\end{array}$ & $\begin{array}{l}46 \% \text { versus } 9 \% \\
(P=.001)\end{array}$ \\
\hline
\end{tabular}


Table 2 Description of the interventions on organ and tissue donation with comparison groups (Continued)

\begin{tabular}{|c|c|c|c|c|c|c|c|c|}
\hline \multirow{3}{*}{$\begin{array}{l}\text { Riker and } \\
\text { White (1995); } \\
\text { United States }\end{array}$} & \multirow{3}{*}{$\begin{array}{l}\text { To evaluate physician response to an } \\
\text { educational program to increase } \\
\text { referral of potential organ or issue } \\
\text { donors in an emergency department }\end{array}$} & \multirow[t]{3}{*}{$\begin{array}{l}\text { Physicians } \\
(n=\text { not mentioned) }\end{array}$} & \multirow{3}{*}{$\begin{array}{l}\text { Educational: } \\
\text { - One-hour conference on the } \\
\text { physician's role in requesting } \\
\text { donation and review the criteria } \\
\text { for donation and services available } \\
\text { from transplant program }\end{array}$} & \multirow[t]{3}{*}{6 months } & \multirow[t]{3}{*}{ - Provide instruction } & \multirow[t]{3}{*}{$\begin{array}{l}\text { Hospital } \\
\text { charts review }\end{array}$} & $\begin{array}{l}\text { Approached } \\
\text { family }\end{array}$ & $\begin{array}{l}65 \% \text { versus } 6.6 \% \\
(P=.001)\end{array}$ \\
\hline & & & & & & & $\begin{array}{l}\text { Obtained } \\
\text { donation consent }\end{array}$ & $\begin{array}{l}32 \% \text { versus } 6.6 \% \\
(P=.08)\end{array}$ \\
\hline & & & & & & & $\begin{array}{l}\text { Organ and/or } \\
\text { tissue donor } \\
\text { recovered }\end{array}$ & $\begin{array}{l}48 \% \text { versus } 5.5 \% \\
(P=.003)\end{array}$ \\
\hline
\end{tabular}




\begin{tabular}{|c|c|c|}
\hline Studies & Outcomes & Risk ratio $(95 \% \mathrm{Cl})$ \\
\hline Dettle et al. (1994) & Approached family & $1.53(0.82,2.85)$ \\
\hline \multirow[t]{2}{*}{ Kittur et al. (1990) } & Referred potential donor & N/A \\
\hline & $\begin{array}{l}\text { Organ and/or tissue } \\
\text { donor recovered }\end{array}$ & N/A \\
\hline Light (1987) & $\begin{array}{l}\text { Organ and/or tissue } \\
\text { donor recovered }\end{array}$ & $1.19(0.45,3.12)$ \\
\hline \multirow[t]{2}{*}{ Nelson et al. (1992) } & Approached family & $1.28(1.01,1.61)$ \\
\hline & Referred potential donor & $5.04(2.79,9.10)$ \\
\hline \multirow[t]{3}{*}{ Riker and White (1995) } & Approached family & $9.71(1.44,65.53)$ \\
\hline & Obtained donation consent & $4.85(0.69,34.28)$ \\
\hline & $\begin{array}{l}\text { Organ and/or tissue } \\
\text { donor recovered }\end{array}$ & $8.67(1.24,60.58)$ \\
\hline
\end{tabular}

donation process, the identification of donor criteria, the HPs' role in the donation process and how to approach family members to initiate discussion.

\section{Discussion}

This systematic review summarized the studies assessing educational and/or organizational interventions aimed at HPs to improve professional practices regarding the donation process or increase donation rates in clinical settings. A total of 15 studies were identified, among which only five had a comparison group. No study referred to a theoretical framework, either for the development of the interventions or their assessment. The behavior change technique most often used consisted of providing instruction on the donation process, including criteria and the role of HPs (how to approach family members, to initiate discussion or how to cope with families' reactions).

Based on our review, the selected interventions aimed at changing HP practices regarding donation were developed, for the most part, more than a decade ago. Recent developments in donation emphasized the introduction of OPO representatives $[46,47]$ and the regulation ensuring donation after death (such as presumed consent) [1]. If organ donation rates increased following the introduction of OPOs in clinical settings $[46,47]$ or following a change in regulations [1], HPs still have to notify procurement organizations of any potential donors, leaving place for more research and interventions to help HPs in the donation process.

\section{Impact on donation-promoting professional practices}

Although there are many interventions aimed at changing HPs' behavior toward the organ and tissue donation process in clinical settings, only a few were carried out exclusively among HPs whose job position requires them to be in contact with patients and who are in a position to ask for donation consent [23,32]. Indeed, most of the interventions also targeted hospital administrators, clerical staff and chaplains [32-34,37]. As such, it is difficult to isolate the impact of these interventions on nurses' and physicians' behavior.

The lack of studies assessing the behavior changes or health outcomes in this literature review is consistent with a recent publication that reviewed the evaluation of interprofessional education programs. According to Kirkpatrick's levels, [25] only 9.7\% of program evaluations assessed changes in behavior, $0.004 \%$ examined organizational practice changes and no items addressed benefits to patients [48]. Similar results were obtained in continuing nursing education programs [49].

\section{Impact on donation rates}

Interestingly, more than half of the studies included used an objective measure of the impact of the intervention on donation rates. This was achieved by extracting the information from medical records to evaluate the number of deaths (potential donors) and the number of actual donors $[23,39,44]$. This type of measure is obviously better than using self-reported behavior and provides more confidence in the observed effects.

\section{Behavior change strategies and underlying theoretical framework}

Surprisingly, in spite of the HPs' role of gatekeeper in the donation process, there is a lack of sound theoretical interventions aimed at improving professional practices regarding the donation process or at increasing donation rates. None of the interventions were developed with reference to a behavior change theory, except the study by Taylor, Young and Kneteman [41], which mentioned the use of the concept of change theory, but without explaining how it was applied.

The fact that the interventions included in the present review had a poor theoretical basis and an inappropriate evaluation of their impact has important clinical implications. OPOs and donation stakeholders seem to apply nontheory-based intervention strategies without being sure of their efficacy. These interventions have an important cost for the healthcare system without resulting in significant changes (for example, increases in donation rates).

\section{Quality of reviewed studies}

The interventions presented several weaknesses in their evaluation designs. For instance, only five of the 15 studies identified used a comparison group to ensure that the intervention effects could be attributed to the implemented change strategy [23,32-35]. In addition, significant methodological flaws (for example, vague definition of the intervention, absence of a theoretical framework, lack of explanations on the study design, unjustified sample size) were noted. 
Table 4 Description of interventions on organ and tissue donation with only pre-post assessments

\begin{tabular}{|c|c|c|c|c|c|c|c|c|}
\hline $\begin{array}{l}\text { Authors (year); } \\
\text { country }\end{array}$ & Purposes & Populations $(n)$ & Interventions & Follow-up & $\begin{array}{l}\text { Behavior change } \\
\text { technique }\end{array}$ & $\begin{array}{l}\text { Study } \\
\text { methodology }\end{array}$ & Outcomes & $\begin{array}{l}\text { Results } \\
\text { (pre } \rightarrow \text { post) }\end{array}$ \\
\hline \multirow{4}{*}{$\begin{array}{l}\text { Alonso, } \\
\text { Fernandez, } \\
\text { Mataix et al. } \\
\text { (1999); Spain }\end{array}$} & \multirow{4}{*}{$\begin{array}{l}\text { To present the results of a pilot } \\
\text { study carried out in Seville, Spain, } \\
\text { evaluating the donor } \\
\text { action program }\end{array}$} & \multirow{4}{*}{$\begin{array}{l}\text { Hospital staff } \\
(n=\text { not mentioned })\end{array}$} & Educational: & \multirow[t]{4}{*}{12 months } & \multirow{4}{*}{$\begin{array}{l}\text { - Provide } \\
\text { instruction }\end{array}$} & \multirow{4}{*}{$\begin{array}{l}\text { Medical } \\
\text { records review }\end{array}$} & \multirow{2}{*}{$\begin{array}{l}\text { Detected } \\
\text { potential } \\
\text { donor }\end{array}$} & \multirow[t]{2}{*}{$81.0 \% \rightarrow 97.5 \%$} \\
\hline & & & $\begin{array}{l}\text { - Training in family } \\
\text { interview and } \\
\text { communication }\end{array}$ & & & & & \\
\hline & & & $\begin{array}{l}\text { - Training in donor } \\
\text { detection and brain } \\
\text { death diagnosis }\end{array}$ & & & & \multirow[t]{2}{*}{$\begin{array}{l}\text { Organ and/or } \\
\text { tissue donor } \\
\text { recovered }\end{array}$} & \multirow[t]{2}{*}{$32.1 \% \rightarrow 44.4 \%$} \\
\hline & & & $\begin{array}{l}\text { - Creating guidelines for } \\
\text { donation process }\end{array}$ & & & & & \\
\hline \multirow{12}{*}{$\begin{array}{l}\text { Beasley, } \\
\text { Capossela, } \\
\text { Brigham, } \\
\text { Gunderson and } \\
\text { Gortmaker (1997); } \\
\text { United States }\end{array}$} & \multirow{12}{*}{$\begin{array}{l}\text { To increase organ donation in } 50 \\
\text { hospitals in three organ } \\
\text { procurement organization service } \\
\text { areas simultaneously by using a } \\
\text { large-scale intervention }\end{array}$} & \multirow{12}{*}{$\begin{array}{l}\text { Physicians, residents, nurses, } \\
\text { social workers, chaplains } \\
\text { and administrators } \\
\text { ( } n=\text { not mentioned) }\end{array}$} & Educational: & \multirow[t]{12}{*}{24 months } & $\begin{array}{l}\text { - Provide } \\
\text { instruction }\end{array}$ & \multirow[t]{12}{*}{$\begin{array}{l}\text { Medical } \\
\text { records review }\end{array}$} & \multirow[t]{2}{*}{$\begin{array}{l}\text { Approached } \\
\text { family }\end{array}$} & \multirow[t]{2}{*}{$\begin{array}{l}69.0 \% \rightarrow 85.6 \% \\
(P=.001)\end{array}$} \\
\hline & & & $\begin{array}{l}\text { - Presentation of donation } \\
\text { protocols }\end{array}$ & & \multirow{11}{*}{$\begin{array}{l}\text { - Provide } \\
\text { feedback on } \\
\text { performance }\end{array}$} & & & \\
\hline & & & $\begin{array}{l}\text { - Review health } \\
\text { professional role in } \\
\text { donation process }\end{array}$ & & & & $\begin{array}{l}\text { Referred } \\
\text { potential } \\
\text { donor }\end{array}$ & $\begin{array}{l}55.5 \% \rightarrow 80.2 \% \\
(P=.001)\end{array}$ \\
\hline & & & - Department meeting & & & & Obtained & $50.9 \% \rightarrow 52.2 \%$ \\
\hline & & & - In-services & & & & $\begin{array}{l}\text { donation } \\
\text { consent }\end{array}$ & \\
\hline & & & Organizational: & & & & Organ and/or & $32.9 \% \rightarrow 42.5 \%$ \\
\hline & & & - Organ donation protocols & & & & $\begin{array}{l}\text { tissue donor } \\
\text { recovered }\end{array}$ & $(P=.005)$ \\
\hline & & & $\begin{array}{l}\text { o Potential donor } \\
\text { identification }\end{array}$ & & & & & \\
\hline & & & $\begin{array}{l}\text { o Notification of the organ } \\
\text { procurement organization }\end{array}$ & & & & & \\
\hline & & & $\begin{array}{l}\text { o Ensuring decoupled } \\
\text { request }\end{array}$ & & & & & \\
\hline & & & $\begin{array}{l}\text { o Private setting to ask } \\
\text { for donation }\end{array}$ & & & & & \\
\hline & & & $\begin{array}{l}\text { o Active inclusion of } \\
\text { organ procurement } \\
\text { organization in request }\end{array}$ & & & & & \\
\hline \multirow{4}{*}{$\begin{array}{l}\text { Bleakley (2010); } \\
\text { United Kingdom }\end{array}$} & \multirow{4}{*}{$\begin{array}{l}\text { To increase the number of } \\
\text { donated organs through an } \\
\text { effective donor identification and } \\
\text { referral scheme in a large acute } \\
\text { hospital's critical care units }\end{array}$} & Clinical staff & Educational: & \multirow[t]{4}{*}{12 months } & \multirow{4}{*}{$\begin{array}{l}\text { - Intervention } \\
\text { not described }\end{array}$} & \multirow{4}{*}{$\begin{array}{l}\text { Not } \\
\text { mentioned }\end{array}$} & \multirow{4}{*}{$\begin{array}{l}\text { Referred } \\
\text { potential } \\
\text { donor }\end{array}$} & \multirow[t]{4}{*}{$4 \rightarrow 121$ (donors) } \\
\hline & & \multirow[t]{3}{*}{$(n=170)$} & $\begin{array}{l}\text { - Education program on } \\
\text { required referral }\end{array}$ & & & & & \\
\hline & & & Organizational: & & & & & \\
\hline & & & $\begin{array}{l}\text { - Hospital policy on how } \\
\text { to make a referral }\end{array}$ & & & & & \\
\hline
\end{tabular}


Table 4 Description of interventions on organ and tissue donation with only pre-post assessments (Continued)

\begin{tabular}{|c|c|c|c|c|c|c|c|c|}
\hline \multirow{8}{*}{$\begin{array}{l}\text { Milanés, Gonzalez, } \\
\text { Hernandez, } \\
\text { Arminio, Clesca } \\
\text { and Rivas- } \\
\text { Vetencourt } \\
\text { (2003); Venezuela }\end{array}$} & \multirow{8}{*}{$\begin{array}{l}\text { To find solutions to the critical } \\
\text { donor shortage situation, and its } \\
\text { negative socioeconomic impact } \\
\text { in our society, by implementing a } \\
\text { transplant coordination program } \\
\text { in a hospital with a variety of } \\
\text { departments, including } \\
\text { neurosurgery and kidney } \\
\text { transplantation }\end{array}$} & \multirow{8}{*}{$\begin{array}{l}\text { Healthcare staff in the } \\
\text { critical care area }(n=97)\end{array}$} & Educational: & \multirow[t]{8}{*}{24 months } & \multirow{8}{*}{$\begin{array}{l}\text { - Provide } \\
\text { instruction }\end{array}$} & \multirow{8}{*}{$\begin{array}{l}\text { Medical } \\
\text { records review }\end{array}$} & \multirow{3}{*}{$\begin{array}{l}\text { Detected } \\
\text { potential } \\
\text { donor }\end{array}$} & \multirow[t]{3}{*}{$8.1 \% \rightarrow 57.5 \%$} \\
\hline & & & $\begin{array}{l}\text { - Detection, identification } \\
\text { and donor criteria }\end{array}$ & & & & & \\
\hline & & & - Death diagnostic & & & & & \\
\hline & & & - Donor maintenance & & & & \multirow{5}{*}{$\begin{array}{l}\text { Organ and/or } \\
\text { tissue donor } \\
\text { recovered }\end{array}$} & \multirow[t]{5}{*}{$1.6 \% \rightarrow 9.1 \%$} \\
\hline & & & $\begin{array}{l}\text { - Organ and tissue } \\
\text { viability studies }\end{array}$ & & & & & \\
\hline & & & $\begin{array}{l}\text { - Family interview, } \\
\text { requesting consent }\end{array}$ & & & & & \\
\hline & & & $\begin{array}{l}\text { - Organ sharing, allocation } \\
\text { and preservation }\end{array}$ & & & & & \\
\hline & & & $\begin{array}{l}\text { - Transplant ethics and } \\
\text { legislation }\end{array}$ & & & & & \\
\hline \multirow{5}{*}{$\begin{array}{l}\text { Niday, Painter, } \\
\text { Peak et al. (2007); } \\
\text { United States }\end{array}$} & \multirow{5}{*}{$\begin{array}{l}\text { To implement and evaluate a } \\
\text { scripted information about organ } \\
\text { and tissue donation for hospice } \\
\text { inpatient on admission }\end{array}$} & Nurses & Educational: & \multirow[t]{5}{*}{6 months } & \multirow{5}{*}{$\begin{array}{l}\text { - Provide } \\
\text { instruction }\end{array}$} & \multirow{5}{*}{$\begin{array}{l}\text { Review of } \\
\text { death records }\end{array}$} & \multirow{2}{*}{$\begin{array}{l}\text { Organ and/or } \\
\text { tissue donor } \\
\text { recovered } \\
\text { (corneal rates) }\end{array}$} & \multirow[t]{2}{*}{$6.3 \% \rightarrow 20.6 \%$} \\
\hline & & \multirow[t]{4}{*}{$(n=12)$} & $\begin{array}{l}\text { - Scripted instruction to } \\
\text { prompt nurses to } \\
\text { introduce the subject of }\end{array}$ & & & & & \\
\hline & & & donation & & & & \multirow{3}{*}{$\begin{array}{l}\text { Organ and/or } \\
\text { tissue donor } \\
\text { recovered } \\
\text { (tissue rates) }\end{array}$} & \multirow[t]{3}{*}{$0.0 \% \rightarrow 0.0 \%$} \\
\hline & & & Organizational: & & & & & \\
\hline & & & $\begin{array}{l}\text { - Give tissue donation } \\
\text { information upon } \\
\text { admission as part of the } \\
\text { normal admission process } \\
\text { and then repeated at the } \\
\text { time of death. }\end{array}$ & & & & & \\
\hline \multirow{6}{*}{$\begin{array}{l}\text { Shafer, Durand, } \\
\text { Hueneke, et al. } \\
\text { (1998); } \\
\text { United States }\end{array}$} & \multirow{6}{*}{$\begin{array}{l}\text { To determine whether donors } \\
\text { could be produced from } \\
\text { non-donor hospitals }\end{array}$} & \multirow{6}{*}{$\begin{array}{l}\text { Nurses and hospital staff } \\
\text { ( } n=25 \text { hospitals) }\end{array}$} & Educational: & \multirow[t]{6}{*}{17 months } & \multirow{6}{*}{$\begin{array}{l}\text { - Intervention } \\
\text { not described }\end{array}$} & \multirow{6}{*}{$\begin{array}{l}\text { Monthly death } \\
\text { records audit }\end{array}$} & \multirow{2}{*}{$\begin{array}{l}\text { Referred } \\
\text { potential } \\
\text { donor (organ) }\end{array}$} & \multirow[t]{2}{*}{$24 \rightarrow 139$ (donors) } \\
\hline & & & - Training activities & & & & & \\
\hline & & & $\begin{array}{l}\text { - Education programs } \\
\text { and materials }\end{array}$ & & & & \multirow{2}{*}{$\begin{array}{l}\text { Referred } \\
\text { potential } \\
\text { donor (tissue) }\end{array}$} & \multirow[t]{2}{*}{$\begin{array}{l}202 \rightarrow 3,931 \\
\text { (donors) }\end{array}$} \\
\hline & & & Organizational: & & & & & \\
\hline & & & $\begin{array}{l}\text { - Develop in-house } \\
\text { coordinators }\end{array}$ & & & & $\begin{array}{l}\text { Organ donor } \\
\text { recovered }\end{array}$ & $8 \rightarrow 44$ (donors) \\
\hline & & & & & & & $\begin{array}{l}\text { Tissue donor } \\
\text { recovered }\end{array}$ & $154 \rightarrow 423$ (donors) \\
\hline \multirow{3}{*}{$\begin{array}{l}\text { Stark, Wikoren } \\
\text { and Martone } \\
\text { (1994); } \\
\text { United States }\end{array}$} & \multirow{3}{*}{$\begin{array}{l}\text { To develop and pilot an organ } \\
\text { donation program that focuses } \\
\text { on the collaborative efforts of the } \\
\text { entire health care team, hospital } \\
\text { administration and organ } \\
\text { procurement agency }\end{array}$} & \multirow{3}{*}{$\begin{array}{l}\text { Physicians, nurses and } \\
\text { hospital personnel } \\
\text { ( } n=\text { not mentioned) }\end{array}$} & Educational: & \multirow[t]{3}{*}{24 months } & - Provide & Not & Detected & $45.7 \% \rightarrow 92.0 \%$ \\
\hline & & & $\begin{array}{l}\text { - Partners in organ } \\
\text { donation program }\end{array}$ & & consequences & mentıoned & potentıal donor & \\
\hline & & & $\begin{array}{l}\text { o Promote positive } \\
\text { attitudes toward donation } \\
\text { (awareness) }\end{array}$ & & $\begin{array}{l}\text { - Provide } \\
\text { instruction }\end{array}$ & & $\begin{array}{l}\text { Obtained } \\
\text { donation } \\
\text { consent }\end{array}$ & $17.1 \% \rightarrow 56.0 \%$ \\
\hline
\end{tabular}

\section{To implement and evaluate a Peak et al. (2007); scripted information about organ and tissue donation for hospice}

To determine whether donors could be produced from Hueneke, et (1998): United State
Physicians, nurses and hospital personnel ( $n=$ not mentioned) 
Table 4 Description of interventions on organ and tissue donation with only pre-post assessments (Continued)

\begin{tabular}{|c|c|c|c|c|c|c|c|c|}
\hline & & & $\begin{array}{l}\text { o Recognize potential } \\
\text { donor }\end{array}$ & & & & & \\
\hline & & & $\begin{array}{l}\text { o Offering the option of } \\
\text { donation }\end{array}$ & & & & & \\
\hline & & & $\begin{array}{l}\text { o Support the grieving } \\
\text { of donor families }\end{array}$ & & & & & \\
\hline & & & Organizational: & & & & & \\
\hline & & & $\begin{array}{l}\text { - Develop nurse } \\
\text { requestor role }\end{array}$ & & & & & \\
\hline \multirow{3}{*}{$\begin{array}{l}\text { Taylor, Young } \\
\text { and Kneteman } \\
\text { (1997); Canada }\end{array}$} & \multirow{3}{*}{$\begin{array}{l}\text { To describe the development of a } \\
\text { program to cross-train critical care } \\
\text { nurses as organ procurement } \\
\text { coordinators }\end{array}$} & \multirow{3}{*}{$\begin{array}{l}\text { Intensive care units nurses } \\
(n=\text { not mentioned })\end{array}$} & Educational: & \multirow{3}{*}{$\begin{array}{l}\text { Not } \\
\text { mentioned }\end{array}$} & \multirow{3}{*}{$\begin{array}{l}\text { - Provide } \\
\text { instruction }\end{array}$} & \multirow{3}{*}{$\begin{array}{l}\text { Not } \\
\text { mentioned }\end{array}$} & \multirow[t]{3}{*}{ Donation rates } & \multirow{3}{*}{$\begin{array}{l}18 \text { donors per } \\
\text { million population } \\
\rightarrow 31 \text { donors per } \\
\text { million population } \\
\text { ( } 72 \% \text { increase rate) }\end{array}$} \\
\hline & & & - Classroom instruction & & & & & \\
\hline & & & $\begin{array}{l}\text { - Preceptor clinical } \\
\text { experience }\end{array}$ & & & & & \\
\hline \multirow{5}{*}{$\begin{array}{l}\text { Van Gelder, Van } \\
\text { Hees, de Roey, } \\
\text { Monbaliu, Aerts, } \\
\text { Coosemans et al. } \\
\text { (2006); Belgium }\end{array}$} & \multirow{5}{*}{$\begin{array}{l}\text { To measure the impact of an } \\
\text { intervention plan designed to } \\
\text { optimize the donor detection } \\
\text { process and donor referral patterns }\end{array}$} & \multirow{5}{*}{$\begin{array}{l}\text { Departments of neurology, } \\
\text { neurosurgery, anesthesiology, } \\
\text { intensive care medicine } \\
\text { and abdominal transplant } \\
(n=\text { not mentioned) }\end{array}$} & Educational: & \multirow[t]{5}{*}{48 months } & $\begin{array}{l}\text { - Provide } \\
\text { instruction }\end{array}$ & \multirow[t]{5}{*}{$\begin{array}{l}\text { Not } \\
\text { mentioned }\end{array}$} & \multirow{4}{*}{$\begin{array}{l}\text { Organ and/or } \\
\text { tissue donor } \\
\text { recovered }\end{array}$} & \multirow[t]{3}{*}{$\begin{array}{l}230 \rightarrow 301 \text { (donors) } \\
(P<.05)\end{array}$} \\
\hline & & & $\begin{array}{l}\text { - Information on donor } \\
\text { criteria }\end{array}$ & & \multirow{4}{*}{$\begin{array}{l}\text { - Provide } \\
\text { feedback on } \\
\text { performance }\end{array}$} & & & \\
\hline & & & $\begin{array}{l}\text { - Communication } \\
\text { between donor and } \\
\text { transplant centers }\end{array}$ & & & & & \\
\hline & & & Organizational: & & & & & \\
\hline & & & - Facilitation of procedure & & & & $\begin{array}{l}\text { Tissue donor } \\
\text { recovered }\end{array}$ & $\begin{array}{l}66 \rightarrow 180 \text { (donors) } \\
(P<.001)\end{array}$ \\
\hline \multirow{8}{*}{$\begin{array}{l}\text { Wight, Cohen, } \\
\text { Roels and } \\
\text { Miranda (2000); } \\
\text { United Kingdom }\end{array}$} & \multirow{8}{*}{$\begin{array}{l}\text { To evaluate the immediate } \\
\text { ( } 6 \text { months), short-term ( } 1 \text { year) } \\
\text { and sustained ( } 2 \text { years) effects of } \\
\text { the Donor Action program on } \\
\text { donation rates in different countries }\end{array}$} & \multirow[t]{8}{*}{$\begin{array}{l}\text { Intensive care units staff } \\
(n=\text { not mentioned })\end{array}$} & Educational: & $\begin{array}{l}12 \text { months } \\
\text { (United } \\
\text { Kingdom) }\end{array}$ & $\begin{array}{l}\text { - Provide } \\
\text { instruction }\end{array}$ & \multirow[t]{8}{*}{$\begin{array}{l}\text { Medical } \\
\text { records review }\end{array}$} & \multirow[t]{6}{*}{$\begin{array}{l}\text { Organ donor } \\
\text { recovered } \\
\text { (United Kingdom.) }\end{array}$} & $\begin{array}{l}122 \% \text { increase } \\
(6 \text { months) }\end{array}$ \\
\hline & & & - Educational program on: & 24 months & - Provide & & & \\
\hline & & & $\begin{array}{l}\text { o Family care and } \\
\text { communication }\end{array}$ & & $\begin{array}{l}\text { Teediback on } \\
\text { performance }\end{array}$ & & & \multirow[t]{4}{*}{$\begin{array}{l}40 \% \text { increase } \\
\text { (12 months) }\end{array}$} \\
\hline & & & o Donor maintenance & & - Prompt & & & \\
\hline & & & o Organ retrieval & & practice & & & \\
\hline & & & Organizational: & & & & & \\
\hline & & & $\begin{array}{l}\text { - Forming a Donor Action } \\
\text { committee }\end{array}$ & & & & $\begin{array}{l}\text { Have referred } \\
\text { potential } \\
\text { donor (Spain) }\end{array}$ & $\begin{array}{l}16 \% \text { increase } \\
\text { ( } 24 \text { months) }\end{array}$ \\
\hline & & & & & & & $\begin{array}{l}\text { Organ donor } \\
\text { recovered } \\
\text { (Spain) }\end{array}$ & $\begin{array}{l}33 \% \text { increase } \\
\text { ( } 24 \text { months) }\end{array}$ \\
\hline
\end{tabular}


Many of the studies included showed nonsignificant improvements in the detection of potential donors, approaching families and achieving consent or increasing donation rates in clinical settings [32,35]. Yet, some studies have proven that providing instruction on the donation process can significantly change HPs' behavior over a period of 6 to 24 months $[23,33]$. However, it was not possible to establish whether an intervention was efficient due to methodological flaws, poorly described population or the lack of details on the content of the interventions and evaluation. Moreover, it was not possible to determine the efficacy of studies only using a prepost evaluation because of the lack of a control group.

\section{Limitations of the systematic review}

The present review has some limitations. Only a small number of studies could be included in the analysis because most did not use a control group to compute a relative risk. Not all interventions reported the required information to compute relative risk (that is, number of participants in the experimental and the control groups). Moreover, the variability of the intervention strategies and the different HP practices on donation prevented the computation of some comparisons and the pooling of relative risks.

\section{Conclusions}

Despite the large number of publications on interventions to improve HPs' practices regarding the donation process or increase donation rates, few of these interventions have been evaluated, or the associated assessments have methodological flaws that make it difficult to draw clear conclusions regarding their efficacy. Therefore, interventions aimed at improving the donation process or increasing donation rates should be based on sound theoretical frameworks and would benefit from more rigorous evaluation methods to ensure good knowledge translation and appropriate organizational decisions to improve professional practices.

\section{Additional file}

Additional file 1: Search strategy for each database.

\section{Abbreviations}

HP: health professional; OPO: organ procurement organization.

\section{Competing interests}

The authors declare that they have no competing interests.

\section{Authors' contributions}

FD contributed substantially to developing and designing the study, acquiring data, analyzing and interpreting data and drafting the manuscript. GG contributed to developing and designing the study, interpreting data and drafting the manuscript. LAVI contributed to extracting data and drafting the manuscript. All authors have read and approved the final manuscript.

\section{Authors' information}

FD is a PhD candidate at the Faculty of Nursing at Laval University (Quebec City, Canada) and a clinical nurse specialist at the Institut de cardiologie et de pneumologie de Québec. GG is a professor at the Faculty of Nursing at Laval University. LAVI is a research professional at the Faculty of Nursing at Laval University.

\section{Acknowledgements}

The authors thank Knowledge Translation Canada (KT Canada) for their financial support.

\section{Author details}

${ }^{1}$ Institut universitaire de cardiologie et de pneumologie de Québec, 2725, chemin Sainte-Foy, Room Y-3495, Quebec, (Quebec) G1V 4G5, Canada. ${ }^{2}$ Ferdinand-Vandry Building, Faculty of Nursing, Laval University, 1050, avenue de la médicine, Quebec, (Quebec) G1K 7P4, Canada.

Received: 10 June 2013 Accepted: 25 February 2014

Published: 14 March 2014

\section{References}

1. Rithalia A, McDaid C, Suekarran S, Myers L, Sowden A: Impact of presumed consent for organ donation on donation rates: a systematic review. BMJ 2009, 338:a3162.

2. Donate Life America: National donor designation report card. [http:// donatelife.net/2013-national-donor-designation-report-card-released/]

3. Conseil Canadien pour le Don et la Transplantation: La demande d'allogreffes de tissus d'origine humaine Rapport final. [http://www.organsandtissues.ca/ s/english-expert/publications/leading-practice-reports]

4. Institut canadien d'information sur la santé: Donneurs d'organes selon le type d'organe, au Canada, de 1998 à 2007. [https://secure.cihi.ca/ free_products/CORR_AiB_FR_20091222_rev20100106.pdf]

5. Nijkamp MD, Hollestelle ML, Zeegers MP, van den Borne B, Reubsaet A: To be(come) or not to be(come) and organ donor, that's the question: a meta-analysis of determinant and intervention studies. Health Psychol Rev 2008, 2:20-40

6. Simpkin AL, Robertson LC, Barber VS, Young JD: Modifiable factors influencing relatives' decision to offer organ donation: systematic review. BMJ 2009, 338:b991.

7. Eccles M, Grimshaw J, Walker A, Johnston M, Pitts N: Changing the behavior of healthcare professionals: the use of theory in promoting the uptake of research findings. J Clin Epidemiol 2005, 58:107-112.

8. Green LW: From research to "best practices" in other settings and populations. Am J Health Behav 2001, 25:165-178.

9. Perleth $M$, Jakubowski $E$, Busse R: What is 'best practice' in health care? State of the art and perspectives in improving the effectiveness and efficiency of the European health care systems. Health Policy 2001, 56:235-250.

10. Wensing $M$, van der Weijden T, Grol R: Implementing guidelines and innovations in general practice: which interventions are effective? $\mathrm{Br}$ Gen Pract 1998, 48:991-997.

11. Abraham C, Michie S: A taxonomy of behavior change techniques used in interventions. Health Psychol 2008, 27:379-387.

12. Baban A, Cranium C: Changing health-risk behaviors: a review of theory and evidence-based interventions in health psychology. J Cogn Behav Psychother 2007, 7:45-67.

13. Webb $T L$, Sheeran $P$ : Does changing behavioral intentions engender behavior change? A meta-analysis of experimental evidence. Psychol Bull 2006, 132:249-268

14. Grimshaw J, Eccles M, Tetroe J: Implementing clinical guidelines: current evidence and future implications. J Contin Educ Health Prof 2004, 24(Suppl 1):S31-S37.

15. Grimshaw JM, Eccles MP, Walker AE, Thomas RE: Changing physicians' behavior: what works and thoughts on getting more things to work. J Contin Educ Health Prof 2002, 22:237-243.

16. Michie S, Johnston M: Theories and techniques of behaviour change: Developing a cumulative science of behaviour change. Health Psychol Rev 2012, 6:1-6.

17. Glanz K, Bishop DB: The role of behavioral science theory in development and implementation of public health interventions. Annu Rev Public Health 2010, 31:399-418. 
18. Tong A, Chapman JR, Wong G, Josephson MA, Craig JC: Public awareness and attitudes to living organ donation: systematic review and integrative systhesis. Transplantation 2013, 96:429-437.

19. Li AH, Rosenblum AM, Nevis IF, Garg AX: Adolescent classroom education on knowledge and attitudes about deceased organ donation: a systematic review. Pediatr Transplant 2013, 17:119-128.

20. Rech TH, Moraes RB, Crispim D, Czepielewski MA, Leitao CB: Management of the bain-dead organ donor: a systematic review and meta-analysis. Transplantation 2013, 95:966-974

21. Bastami S, Matthes O, Krones T, Biller-Andorno N: Systematic review of attitudes toward donation after cardiac death among healthcare providers and the general public. Crit Care Med 2013, 41:897-905.

22. Blok GA, van Dalen J, Jager KJ, Ryan M, Wijnen RMH, Wight C, Morton JM, Morley M, Cohen B: The European Donor Hospital Education Programme [EDHEP]: Addressing the training needs of doctors and nurses who break bad news, care for the bereaved, and request donation. Transp/ Int 1999, 12:161-167.

23. Riker RR, White BW: The effect of physician education on the rates of donation request and tissue donation. Transplantation 1995, 59:880-884.

24. Shafer TJ, Wagner D, Chessare J, Zampiello FA, McBride V, Perdue J: Organ donation breakthrough collaborative: increasing organ donation through system redesign. Crit Care Nurse 2006, 26:33-42. 44-48; quiz 49.

25. Kirkpatrick D: Great ideas revisited. Techniques for evaluating training programs. Revisiting Kirkpatrick's four-level model. Train Dev 1996, 50:54-59.

26. Morrison JM, Sullivan F, Murray E, Jolly B: Evidence-based education: development of an instrument to critically appraise reports of educational interventions. Med Educ 1999, 33:890-893.

27. Reed D, Price EG, Windish DM, Wright SM, Gozu A, Hsu EB, Beach MC, Kern D, Bass EB: Challenges in systematic reviews of educational intervention studies. Ann Intern Med 2005, 142:1080-1089.

28. Fishbein M, Ajzen I (Eds): Belief, attitude, intention and behavior: an introduction to theory and research. Reading: Addison-Wesley; 1975

29. Ajzen I: The theory of planned behaviour. Organ Behav Hum Decis Process 1991, 50:179-211.

30. Bandura A (Ed): Social foundations of thought and action: a social cognitive theory. Englewood Cliffs: Prentice Hall; 1986.

31. Fisher JD, Fisher WA: Changing AIDS-risk behaviour. Psychol Bull 1992 11:455-474

32. Dettle E, Sagel B, Chrysler G: Impact of traditional hospital development and education on the knowledge, attitudes, and comfort level of hospital staff toward tissue/organ donation. J Transp/ Coord 1994, 4:38-43.

33. Nelson K, Marymont R, Durand R, Reyes D, Davis R: Evaluation of the impact of an OPO's educational efforts... organ procurement organization. J Transp/ Coord 1992, 2:117-121.

34. Kittur DS, McMenamin J, Knott D: Impact of an organ donor and tissue donor advocacy program on community hospitals. Am Surg 1990, 56:36-39.

35. Light DE: Cornea donation: increasing tissue supplies. South Med J 1987, 80:1542-1545.

36. Alonso M, Fernandez M, Mataix R, Rincon MD, Corrales JA, Burgos R, Miranda B: Donor action in Spain: a program to increase organ donation. Transplant Proc 1999, 31:1084-1085.

37. Beasley $\mathrm{CL}$, Capossela $\mathrm{CL}$, Brigham LE, Gunderson S, Weber P, Gortmaker SL: The impact of a comprehensive, hospital-focused intervention to increase organ donation. J Transp/ Coord 1997, 7:6-13.

38. Milanes CL, Gonzalez L, Hernandez E, Arminio A, Clesca P, Rivas-Vetencourt PA: Transplant coordination program: a useful tool to improve organ donation in Venezuela. Prog Transplant 2003, 13:296-298.

39. Niday P, Painter C, Peak J, Bennett E, Wiley M, McCartt L, Teixeira OHP: Family and staff responses to a scripted introduction to tissue donation for hospice inpatients on admission. Prog Transplant 2007, 17:289-294.

40. Shafer TJ, Durand R, Hueneke MJ, Wolff WS, Davis KD, Ehrle RN, van Buren CT, Orlowski JP, Reyes DH, Gruenenfelder RT, White CK: Texas non-donor-hospital project: a program to increase organ donation in community and rural hospitals. J Transp/ Coord 1998, 8:146-152.

41. Taylor P, Young K, Kneteman N: Intensive care nurses' participation in organ procurement: impact on organ donation rates. Transplant Proc 1997, 29:3646-3648.

42. Stark J, Wikoren B, Martone L: Partners in organ donation: piloting a successful nurse requestor program. Crit Care Nurs Clin North Am 1994 6:591-598.
43. van Gelder F, van Hees D, de Roey J, Monbaliu D, Aerts R, Coosemans W, Daenen W, Pirenne J: Implementation of an intervention plan designed to optimize donor referral in a donor hospital network. Prog Transplant 2006, 16:46-51.

44. Wight C, Cohen B, Roels L, Miranda B: Donor action: A quality assurance program for intensive care units that increases organ donation. J Intensive Care Med 2000, 15:104-114.

45. Bleakley G: Implementing minimum notification criteria for organ donation in an acute hospital's critical care units. Nurs Crit Care 2010, 15:185-191.

46. Shafer TJ, Kappel DF, Heinrichs DF: Strategies for success among OPOs: a study of three organ procurement organizations. J Transp/ Coord 1997, 7:22-31.

47. Presnell SM: Organ procurement organizations: educational programs and social marketing. Tallahassee: Florida State University; 2001.

48. Gillan C, Lovrics E, Halpern E, Wiljer D, Harnett N: The evaluation of learner outcomes in interprofessional continuing education: a literature review and an analysis of survey instruments. Med Teach 2011, 33:e461-e470.

49. Gijbels H, O'Connell R, Dalton-O'Connor C, O'Donovan M: A systematic review evaluating the impact of post-registration nursing and midwifery education on practice. Nurse Educ Pract 2010, 10:64-69.

doi:10.1186/2047-1440-3-8

Cite this article as: Douville et al:: Organ and tissue donation in clinical settings: a systematic review of the impact of interventions aimed at health professionals. Transplantation Research 2014 3:8.

\section{Submit your next manuscript to BioMed Central and take full advantage of:}

- Convenient online submission

- Thorough peer review

- No space constraints or color figure charges

- Immediate publication on acceptance

- Inclusion in PubMed, CAS, Scopus and Google Scholar

- Research which is freely available for redistribution

Submit your manuscript at www.biomedcentral.com/submit
C Biomed Central 